\title{
Conservation value of the Egoli Granite Grassland, an endemic grass- land in Gauteng, South Africa
}

\section{G.J. Bredenkamp, L.R. Brown and M.F. Pfab}

\author{
Bredenkamp, G.J., L.R. Brown and M.F. Pfab. 2006. Conservation value of the Egoli \\ Granite Grassland, an endemic grassland in Gauteng, South Africa. Koedoe 49(2): \\ 59-66. Pretoria. ISSN 0075-6458.
}

\begin{abstract}
Gauteng is the most densely populated province in South Africa. Its remaining natural areas are constantly under threat from urban development and the associated impacts. Presently, the natural areas of Gauteng support a large diversity of ecosystems. One such ecosystem is the Egoli Granite Grassland, endemic to the province, poorly conserved and therefore highly threatened. This paper describes the original Egoli Granite Grassland and the anthropogenic Hyparrhenia hirta dominated grassland that has replaced it in many of the remnant areas. Human impacts on this sensitive ecosystem have resulted in an altered species composition, loss of many species, and a change from a species-rich grassland with high conservation value to a species-poor grassland with low conservation value. The conservation of the last remaining relicts of original Egoli Granite Grassland is essential.
\end{abstract}

Keywords: Egoli Granite Grassland; conservation value; Hyparrhenia hirta, Gauteng.

\begin{abstract}
G.J. Bredenkamp, African Vegetation and Plant Diversity Research Centre, University of Pretoria; L.R. Brown, Applied Behavioural Ecology and Ecosystem Research Unit, University of South Africa; M.F. Pfab, Bioregional Planning, Gauteng Department of Agriculture, Conservation and Environment, Johannesburg, 2001 South Africa.
\end{abstract}

\section{Introduction}

The Egoli Granite Grassland is a type of grassland and a mapping unit (Gm10) classified under the Mesic Highveld Grassland Bioregion according to the new Vegetation Map of South Africa, Lesotho and Swaziland (Mucina et al. 2005). This grassland was mapped as Bankenveld (veld type 61) by Acocks (1988), and Rocky Highveld Grassland (Vegetation Type 34) by Bredenkamp \& Van Rooyen (1996). Acocks (1988) describes the Bankenveld as a False Grassveld Type. The climax vegetation of this veld type should be, according to Acocks, an open savanna, that is a bushveld vegetation, but it has been changed to, and maintained as grassveld by regular veld fires. However, Bredenkamp \& Brown (2003) consider Bankenveld vegetation as a mosaic of grassland and woodland communities controlled by (micro-)climatic conditions that exist in the topographically heterogeneous landscape in the transition zone between the Grassland and Savanna biomes.

From a conservation planning or urban development viewpoint, the range of structural and floristic variation is considered too large to define Bankenveld as a single unit, even on the reconnaissance level of vegetation investigation. Bredenkamp \& Brown (2003) recognised 16 major vegetation types within Bankenveld. The Egoli Granite Grassland is considered as mainly belonging to the Hyparrhenia hirta Anthropogenic Grassland (Bredenkamp \& Brown 2003).

Egoli Granite Grassland is restricted to the Gauteng Province of South Africa and is located north of the Roodepoort / Krugersdorp ridge complex and stretches over a distance of approximately $35 \mathrm{~km}$ to Centurion in the north. This grassland stretches over a distance of approximately $50 \mathrm{~km}$ in a westerly direction from the R21 highway in the east. The $28^{\circ}$ longitude and $26^{\circ}$ latitudi- 


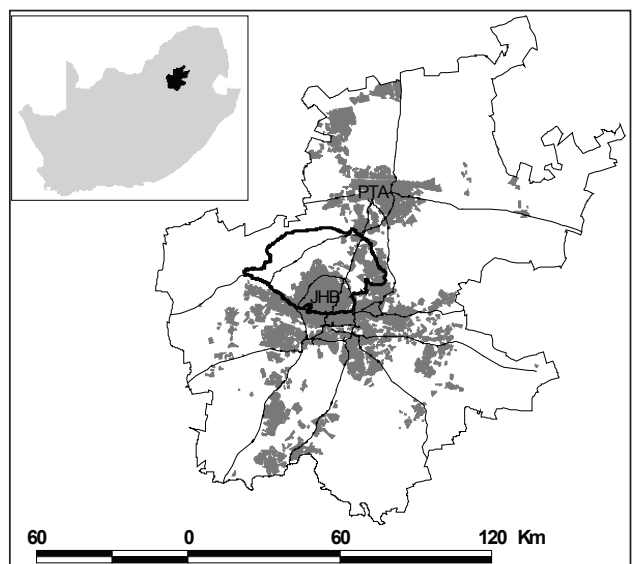

Fig. 1. Locality map of the Egoli Granite Grassland. Grey areas indicate urbanisation

nal lines cross in the centre of this grassland (Fig. 1).

Due to high demand for developable land in Gauteng, and especially the Johannesburg / Pretoria corridor, the Egoli Granite Grassland is under extreme pressure. Large areas are already developed for residential, industrial and commercial purposes. This has led to the destruction of vast tracts of this grassland. At least $61 \%$ of Egoli Granite Grassland has been permanently transformed: $27 \%$ by urban development (Fig. 2); 17\% by smallholdings; $12 \%$ by agriculture (cultivated lands); and $5 \%$ by other impacts such as exotic plantations, mining and planted pastures. An estimated additional $17 \%$ of Egoli Granite Grassland is degraded due to overgrazing and the influence of edge effects associated with a highly fragmented landscape (Fahrig 2003). Other effects, such as trampling, increased pollutants and the infestation of weeds and alien species also contribute to degradation of this grassland. It is therefore highly likely that the national target for conservation of this grassland type, i.e., $25 \%$ of the total extent, will never be realised.

Egoli Granite Grassland is extremely poorly conserved, with only $0.02 \%$ (26 ha) of the vegetation type currently protected, includ-

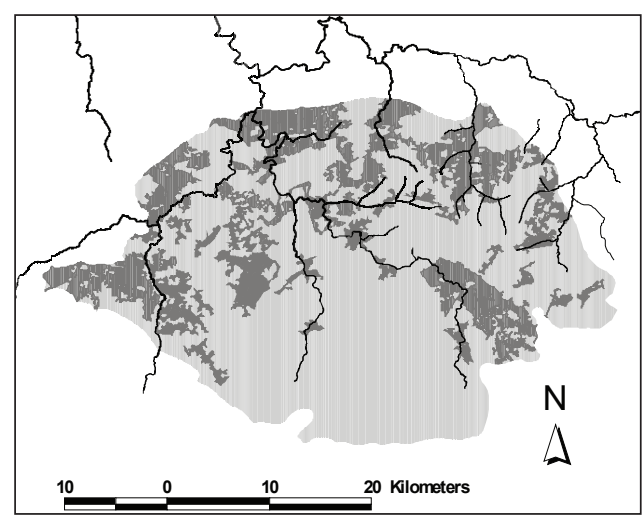

Fig. 2. Dark gray represents remnant areas of potentially original Egoli Granite Grassland; perennial rivers shown.

ing 3 ha in Glen Austin Bird Sanctuary, 3 ha in Melville Koppies Nature Reserve, 9 ha in Ruimsig Nature Reserve, and 11 ha in the Walter Sisulu Botanical Gardens (Fig. 2). The current protection status of Egoli Granite Grassland is therefore completely inadequate, with only $0.1 \%$ of the national target actually achieved. In order to meet South Africa's international obligations, it is imperative that the Gauteng provincial government put in place measures to improve the conservation status of Egoli Granite Grassland.

Any viable remnant patch of original Egoli Granite Grassland must therefore be protected from transforming land uses. In order to assess whether a valuable remnant patch will be affected by a proposed development, environmental consultants involved in vegetation impact assessments are required by the Gauteng Department of Agriculture, Conservation and Environment (GDACE) to assess the presence and condition of Egoli Granite Grassland on any site proposed for development.

As this grassland was only recently defined with the development of the new Vegetation Map of South Africa, Lesotho and Swaziland (Mucina et al. 2005), very little information on its floristic composition, condition, the 
extent of the grassland, and the management thereof exists, causing some confusion among nature conservationists, environmental consultants and local authorities. The aim of this paper is therefore to provide an ecological overview of this grassland.

\section{Physical Environment}

This area is generally characterised by rocky undulating plains representing crests, slopes and valley bottoms with shallow, nutrientpoor soils. Shallow drainage lines and vleilike wetland areas occur in the valley bottoms. Rockiness of the soil surface is a further common characteristic shared by most Bankenveld areas.

Mean monthly temperature in the study area is $16.8^{\circ} \mathrm{C}$ with a mean maximum of $22.6^{\circ} \mathrm{C}$ and a mean minimum of $10.8^{\circ} \mathrm{C}$. The mean winter temperature is $13.8^{\circ} \mathrm{C}$ and mean summer temperature, $25.6^{\circ} \mathrm{C}$ (Weather Bureau 2000; Grobler et al. 2002). Mean annual rainfall in Gauteng is $670 \mathrm{~mm}$ (Gauteng 1997).

Old granitic and gneissic rocks at least 2400 million years old (Kerfoot 1987) are exposed in the Egoli Granite Grassland area. The Halfway House Granites (Fig. 3) of the Johannesburg Dome are intensively weathered with deep drainage lines resulting in a gently rolling topography, with shallow, coarse, nutrient-poor, well-drained soils. The granite areas are mostly covered by grassland vegetation though patches of woodland vegetation are found at sheltered sites on hillslopes and rocky outcrops within this veld type (Grobler 2000; Grobler et al. 2002, 2006).

The $\mathrm{Bb}$ land type predominates over the entire region (Land Type Survey Staff 1984, 1985, 1987) (Fig.3). The residual granitic soils are very shallow and poorly drained. The A horizon is often sandy and light in colour with little organic matter and with an increase in clay content with depth. The soils are invariably acid and very rich in silica (Kerfoot 1987).

\section{Vegetation}

\section{Current vegetation}

This tall grassland occurs over vast areas, usually on shallow, leached soils on the Johannesburg Granite Dome. Disturbed grassland or other disturbed areas such as road reserves or old fields, not cultivated for some years, are also usually Hyparrhenia species-dominated and low in species richness. Although some of these tall grasslands appear to be quite natural, they are mostly associated with an anthropogenic influence from recent or even iron-age times.

These grasslands are characterised by the tall-growing dominant grass Hyparrhenia hirta and the invader dwarf shrub Seriphium plumosum (=Stoebe vulgaris), indicating its low successional status or degraded condition.

Dense Hyparrhenia species-dominated grassland mostly has low species richness, with only a few other species able to establish or survive in the shade of the dense sward of tall grass. Most of these species are relict pioneers or early seral species. The most prominent species include the grasses Cynodon dactylon, Eragrostis chloromelas, E. racemosa, E. curvula and Aristida congesta. Forbs are rarely encountered, though a few individuals of species such as Anthospermum hispidulum, Pseudognaphalium luteo-album, Conyza albida, C. podocephala, Crabbea angustifolia, Helichrysum nudifolium and $H$. rugulosum are often present. The woody layer, which has a very low cover, consists of small clumps of indigenous trees and shrubs widely scattered within this grassland. The scanty woody species include the trees Rhus pyroides and Ziziphus mucronata, together with the scandent shrub Ziziphus zeyheriana. Declared alien invasive species such as Melia azedarach, Eucalyptus species, Pinus species and planted ornamentals are often present.

Typical species found in anthropogenic Hyparrhenia hirta-dominated Egoli Granite Grassland are indicated below: 
- $\quad$ Trees and Shrubs

Acacia caffra (Thunb.) Willd.

*Eucalyptus species

Gymnosporia buxifolia L. Szysyal

* Melia azedarach L.

Olea europaea L. ssp. africana (Mill.) P.S.Green

*Pinus species

Rhus lancea L.f.

Rhus leptodictya Diels

Rhus pyroides Burch.

Ziziphus mucronata Willd.

Ziziphus zeyheriana Sond.

\section{- $\quad$ Grasses}

Aristida bipartita (Nees) Trin. \& Rupr.

Aristida canescens Henrard

Aristida congesta Roem. \& Schult. ssp. barbicollis

(Trin. \& Rupr.) De Winter

Aristida congesta Roem. \& Schult. ssp. congesta

Cynodon dactylon (L.) Pers.

Diheteropogon amplectens (Nees) Clayton

Elionurus muticus (Spreng.) Kunth

Eragrostis chloromelas Steud.

Eragrostis curvula (Schrad.) Nees

Eragrostis gummiflua Nees

Eragrostis plana Nees

Eragrostis racemosa (Thunb.) Steud.

Eragrostis rigidior Pilg.

Heteropogon contortus (L.) Roem. \& Schult.

Hyparrhenia filipendula (Hochst.) Stapf

Hyparrhenia hirta (L.) Stapf

Melinis repens (Willd.) Zizka

Pogonarthria squarrosa (Roem. \& Schult.) Pilg. Sporobolus africanus (Poir.) Robyns \& Tournay

Trichoneura grandiglumis (Nees) Ekman

\section{- $\quad$ Forbs}

Acalypha angustata Sond.

Anthospermum hispidulum E.Mey. ex Sond.

Asparagus laricinus Burch.

Asparagus suaveolens Burch.

Bidens formosa (Bonato) Sch.Bip.

Bidens pilosa $\mathrm{L}$.

Chamaecrista mimosoides (L.) Greene

Cirsium vulgare (Savi) Ten.

Commelina africana $\mathrm{L}$.

Conyza albida Spreng.

Cucumis zeyheri Sond.

Cyperus species

Elephantorrhiza elephantina (Burch.) Skeels

Felicia muricata (Thunb.) Nees

Gazania krebsiana Less.

Geigeria burkei Harv.

Gomphocarpus fruticosus (L.) Aiton f.

Helichrysum nudifolium (L.) Less.

Helichrysum rugulosum Less.

Hermannia depressa N.E.Br.

Hibiscus aethiopicus

Hypoxis rigidula

Lactuca species

Ledebouria marginata (Baker) Jessop
Nidorella hottentotica DC.

Pseudognaphalium luteo-album (L.) Hilliard \& B.L.Burtt

Schkuhria pinnata (Lam.) Cabrera

Seriphium plumosum L.

Tagetes minuta L.

Verbena bonariensis L.

Verbena brasiliensis Vell.

Vernonia oligocephala (DC.) Sch.Bip. ex Walp.

Walafrida densiflora (Rolfe) Rolfe

Zinnia peruviana (L.) L.

\section{Original vegetation}

The original vegetation is thought to be typical Bankenveld (Acocks 1988) or Rocky Highveld Grassland (Bredenkamp \& Van Rooyen 1996). Bredenkamp \& Brown (1998) found a few relict sites which indicate that the original vegetation on the shallow granitic soils of the Johannesburg Granite Dome could have been a variant of the Monocymbium ceressiforme-Loudetia simplex Grassland (Bredenkamp \& Brown 2003). This vegetation is found in areas where little or no disturbance is evident.

The herbaceous layer covers approximately $80 \%$ and is dominated by the grasses Loudetia simplex, Trachypogon spicatus, Schizachyrium sanguineum, Monocymbium ceresiiforme, Digitaria monodactyla, Eragrostis racemosa, Andropogon shirensis, Brachiaria serrata, Alloteropsis semialata, Bewsia biflora and Themeda triandra.

The woody layer consists mainly of a few scattered individuals of the trees Rhus pyroides, $R$. leptodictya, Ziziphus mucronata, the dwarf shrubs Protea welwitschii, Lopholaenia coriifolia, and the geoxylophyte Parinari capensis that are locally prominent. The grasses Panicum natalense, Urelytrum agropyroides, Tristachya leucothrix, Cymbopogon excavatus and Elionurus muticus are also abundant together with the forbs Cyanotis speciosa, Bulbostylis burchellii, Crabbea acaulis, Anthospermum hispidulum and Senecio venosus. The grass Hyparrhenia hirta is often present and may become more prominent at disturbed sites.

This grassland is characterised by a high species richness with a patchy dominance of 


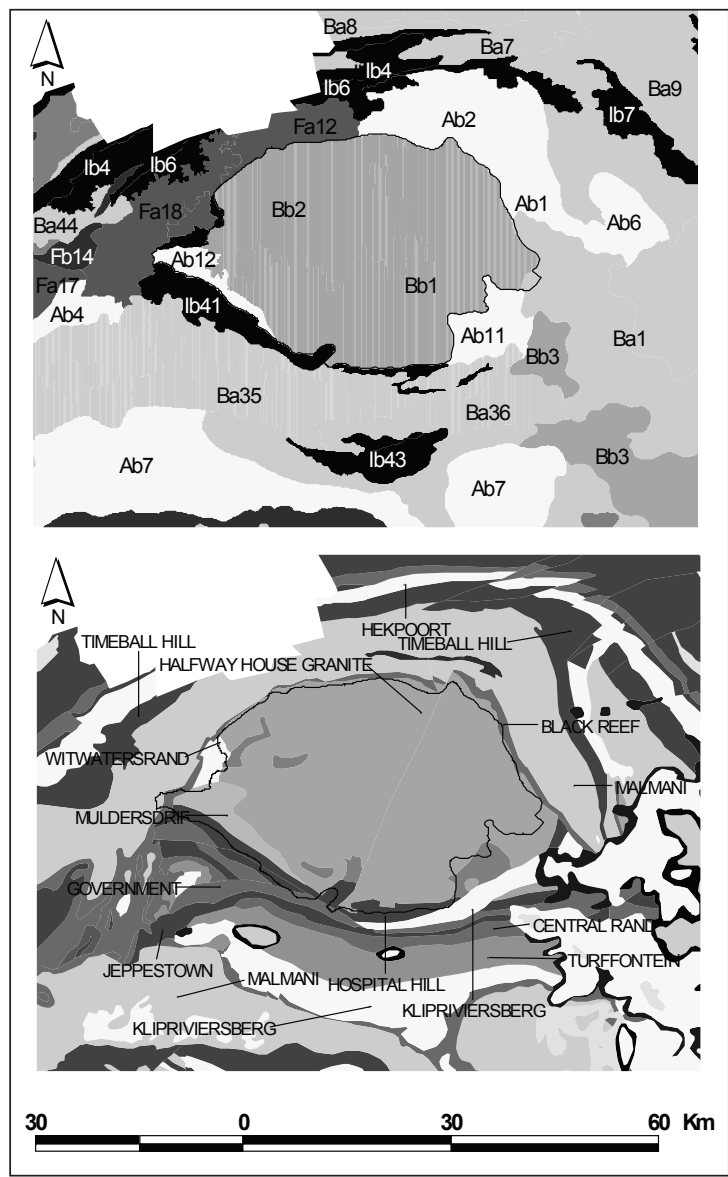

Fig. 3. Land Types (above) and Geology (bottom) within the Egoli Granite Grassland
Olea europaea L. ssp. africana (Mill.) P.S.Green

Rhus lancea L.f.

Rhus leptodictya Diels

Rhus pyroides Burch.

Ziziphus mucronata Willd.

Ziziphus zeyheriana Sond.

\section{- $\quad$ Grasses}

Andropogon schirensis A.Rich.

Aristida adscensionis L.

Aristida canescens Henrard

Aristida congesta Roem. \& Schult. ssp. congesta

Brachiaria serrata (Thunb.) Stapf

Cymbopogon excavatus (Hochst.) Stapf ex Burtt Davy

Cymbopogon pospischilli (K.Schum.) C.E. Hubb

Cynodon dactylon (L.) Pers.

Digitaria brazzae (Franch.) Stapf

Diheteropogon amplectens (Nees) Clayton

Elionurus muticus (Spreng.) Kunth

Eragrostis chloromelas Steud.

Eragrostis curvula (Schrad.) Nees

Eragrostis racemosa (Thunb.) Steud.

Harpochloa falx (L.f.) Kuntze

Heteropogon contortus (L.) Roem. \& Schult.

Hyparrhenia hirta (L.) Stapf

Melinis repens (Willd.) Zizka

Monocymbium ceresiiforme (Nees) Stapf

Panicum natalense Hochst.

Schizachyrium sanguineum (Retz.) Alston

Sporobolus pectinatus Hack.

Themeda triandra Forssk.

Trachypogon spicatus (L.f.) Kuntze

Trichoneura grandiglumis (Nees) Ekman

Tristachya leucothrix Nees

Tristachya rehmannii Hack

\section{- $\quad$ Forbs}

Acalypha angustata Sond.

Aloe transvaalensis Kuntze

various grass species and a large variety of forbs (Louw 1970), representing a climax or close to climax condition. Grazing by cattle is often found in this vegetation type, but the dominance of sour grass species often results in a low nutrient status of the grass during winter (Kerfoot 1987; Bredenkamp \& Van Rooyen 1996).

Typical species found in the original Egoli Granite Grassland are indicated below:

\footnotetext{
Trees and shrubs

Acacia caffra (Thunb.) Willd.

Celtis africana Burm.f.

Elephantorrhiza elephantina (Burch.) Skeels

Gymnosporia buxifolia L. Szysyal
}

Aloe greatheadii Schönland

Anthericum species

Anthospermum hispidulum E.Mey. ex Sond.

Asparagus suaveolens Burch.

Aster bakeranus Burtt Davy ex C.A.Sm.

Babiana hypogea Burch.

Becium obovatum (E.Mey. ex Benth.) N.E.Br.

Blepharis subvolubilis C.B.Clarke

Boophane disticha (L.f.) Herb.

Bulbostylis hispidula (Vahl) R.W.Haines

Chascanum hederaceum (Sond.) Moldenke var. hederaceum

Chaetacanthus burchellii Nees

Chlorophytum fasciculatum (Baker) Kativu

Crabbea acaulis N.E.Br.

Crabbea angustifolia Nees

Crassula capitella Thunb. ssp. capitella

Crinum bulbispermum (Burm.f.) Milne-Redh. \& Schweick. 
Cucumis zeyheri Sond.

Dicoma anomala Sond.

Eriosema cordatum E.Mey.

Eulophia species

Felicia muricata (Thunb.) Nees

Gladiolus crassifolius Baker

Gnidia capitata L.f.

Haplocarpha scaposa Harv.

Helichrysum aureonitens Sch.Bip.

Helichrysum miconiifolia Hilliard

Helichrysum nudifolium (L.) Less.

Hermannia depressa N.E.Br.

Hypericum aethiopicum (Bret.) N.K.B.

Hypericum lalandii Choisy

Hypoxis hemerocallidea Fisch. \& Mey.

Hypoxis multiceps Buchinger ex Baker

Hypoxis rigidula Baker

Ipomoea obscura (L.) Ker Gawl.

Ipomoea ommaneyi Rendle

Justicia anagalloides (Nees) T.Anderson

Kohautia amatymbica Eckl. \& Zeyh.

Ledebouria ovatifolia (Baker) Jessop

Ledebouria marginata (Baker) Jessop

Lotononis foliosa Bolus

Mariscus congestus (Vahl) C.B.Clarke

Neorautanenia ficifolius (Benth.) C.A.Sm.

Pentanisia angustifolia (Hochst.) Hochst.

Pentanisia prunelloides Klotzsch ex Eckl. \& Zeyh.) Walp.

Raphionacme hirsuta (E.Mey.) R.A.Dyer ex E.Phillips

Scabiosa columbaria L.

Schistostephium crataegifolium (DC.) Fenzl ex Harv.

Senecio venosus Harv.

Tephrosia capensis (Jacq.) Pers.

Triumfetta sonderi Ficalho \& Hiern

Tulbaghia acutiloba Harv.

Turbina oblongata (E.Mey. ex Choisy) A.Meeuse

Ursinia nana DC.

Vernonia natalensis Sch.Bip. ex Walp.

Vernonia oligocephala (DC.) Sch.Bip. ex Walp.

\section{Origin of the current vegetation}

The shallow, nutrient-poor soils provide a habitat suited to the climax vegetation as discussed previously. Some nutrients are available in the topsoil, supplemented from fallen leaf litter and decomposition, and also from ashes of burned herbaceous layer (if there was a fire). Nutrients are quickly utilised by plants and are furthermore also quickly leached from the very coarse sandy soils. Nutrient cycling is therefore very rapid.

The system is quite stable and fairly predictable without much change caused by normal droughts or grazing. However, if overgrazed or disturbed to such an extent that degradation proceeds beyond a threshold, then recovery is very slow, due to reduced nutrient cycling and decreased nutrient availability and the vegetation may change to another domain of attraction (Bosch 1989), different from the original climax vegetation, representing a plagioclimax (Fig. 4). A change back to the original domain of attraction is unlikely if not impossible in the short and medium term. Due to the granitically derived shallow nutrient poor soils these systems are sensitive and intolerant to frequent impacts such as heavy grazing, ploughing, trampling and general domestic activities. Thus degradation occurs easily resulting in a change from the climax (high species richness) vegetation to an anthropogenic Hyparrhenia hirta (low species richness) dominated vegetation type.

Very often Hyparrhenia species-dominated grasslands occur on ancient lands in the Central Variation of the Bankenveld (Acocks 1988) and in the surroundings of archaeological sites (Bredenkamp \& Brown 2003), where the inhabitants had a mosaic of cultivated lands and grazing of domestic stock. The more recent European settlers also had a profound effect on the natural vegetation as they developed the cities of Johannesburg and Pretoria following the discovery of gold more than a century ago. It seems that the degraded sites developed into Hyparrhenia species-dominated grasslands, which tend to be stable for a very long time. Moll (1965) and Smits et al. (1999) also indicated that Hyparrhenia species-dominated tall grasslands are anthropogenic in origin.

\section{Importance}

The substrate of the Johannesburg Granite Dome (Halfway House Granites, Fig. 3) is suitable for development. The area is well situated between Johannesburg, the economic powerhouse of South Africa, and Pretoria the administrative capital of the country. There is an enormous demand for developable land in this area, which has resulted in the loss of large tracts of the original Egoli Granite Grassland. Due to general disturbance, ploughing and degradation, an esti- 
mated $60 \%$ of the remaining original Egoli Granite Grassland has been transformed to Hyparrhenia hirta dominated grassland. Only relatively small scattered pockets of the original grassland are still intact and these are considered rare and highly threatened. Due to its high species richness and restricted occurrence, this endemic grassland has a high conservation value.

Furthermore, the bottomland areas and wetlands within the Egoli Granite Grassland provide suitable habitat for various sensitive fauna species such as the Grass Owl Tyto capensis (Red Listed), Marsh Sylph Metisella meninx (Vulnerable), and the Giant Bullfrog Pyxicephalus adspersus (Near Threatened).

\section{Conclusion}

Egoli Granite Grassland is a poorly conserved, severely transformed, highly fragmented and degraded vegetation type. It is estimated that only $22 \%$ of the original extent of Egoli Granite Grassland remains in its original state. Many of these remnant areas are likely to be destroyed in the near future due to previously authorised developments (e.g. Cosmo City to the north-west of Johannesburg) or illegal activities. It is therefore essential that any viable remnant patch of original Egoli Granite Grassland is conserved.

Areas associated with transformed grassland, where Hyparrhenia hirta is dominant and species richness is low, have a low value with respect to achieving the national conservation target for Egoli Granite Grassland. It should be noted however, that Hyparrhenia hirta dominated grassland may be valuable for the conservation of sensitive fauna, e.g. Grass Owl (Tyto capensis) and Giant Bullfrog (Pyxicephalus adspersus).

A mixture of various grasses and high forb diversity renders the original Egoli Granite Grassland with a high conservation value and conservation of remnant areas is especially

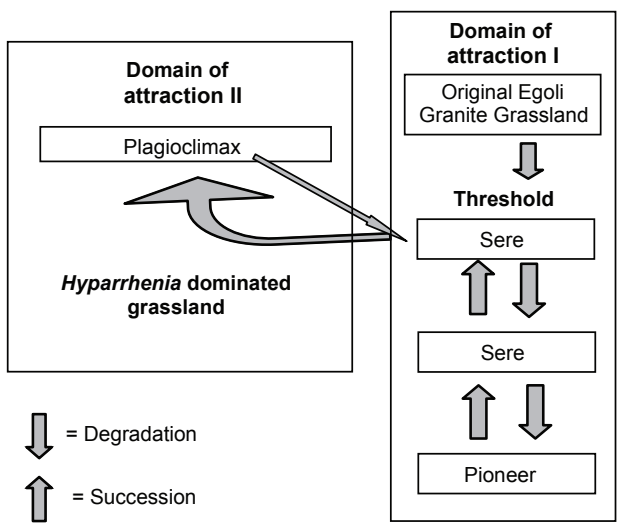

Fig. 4. A model indicating degradation of original Egoli Granite Grassland climax and succession towards a Hyparrhenia hirta dominated vegetation type.

important since it is unlikely that the transformed anthropogenic grassland will return to the original climax vegetation.

Since Egoli Granite Grassland is endemic to Gauteng, its protection is both a provincial and national priority. It also forms part of a global ecoregion in crisis, an area where biodiversity and ecosystem services are at greatest risk and focused on-the-ground conservation action are required (Hoekstra et al. 2005).

\section{References}

Acocks, J.P.H. 1988. Veld types of South Africa. 3rd ed. Memoirs of the botanical Survey of South Africa 57: 1-146.

BARNES, K.N. (ed.) 2000. The Escom Red Data Book of Birds of South Africa, Lesotho and Swaziland. Johannesburg: BirdLife South Africa.

Bosch, O.J.H. 1989. Degradation of the semi-arid grasslands of southern Africa. Journal of Arid Environments 16: 165-175.

BredenKAMP, G.J \& L.R. BROWN. 1998. A vegetation assessment of the northern areas of the Northern Metropolitan local Council. Pretoria: Ekotrust cc. Unpublished report.

Bredenkamp, G.J \& L.R. Brown. 2003. A reappraisal of Acocks' Bankenveld: origin and diversity of vegetation types. South African Journal of Botany 69(1): 7-26. 
BREDENKAMP, G.J. \& N. VAN RoOyen. 1996. Rocky Highveld Grassland. P. 39. In: Low, A.B. \& A.G. ReBelo (eds.). Vegetation of South Africa, Lesotho and Swaziland. Pretoria: Department of Environmental Affairs \& Tourism,

FAHRIG, L. 2003. Effects of habitat fragmentation on biodiversity. Annua. Review of Ecology Evolution and Systematics 34: 487-515.

GAUTENG, 1997. State of the Environment in Gauteng: A preliminary report. Gauteng Department of Agriculture, Conservation and Environment. Unpublished report, CSIR Environmentek.

Kerfoot, O. 1987. The geology, physiography and vegetation of the Witwatersrand floral region. Pp. 1-7. In: Lowrey, T.K. \& S. Wright (eds.). The flora of the Witwatersrand Volume 1: The Monocotyldonae. Johannesburg: Witwatersrand University Press.

Grobler, C.H. 2000. The vegetation ecology of urban open spaces in Gauteng. MSc thesis, University of Pretoria, Pretoria.

Grobler, C.H., G.J. Bredenkamp, L.R. Brown. 2002. Natural woodland vegetation and plant species richness of the urban open spaces in Gauteng, South Africa. Koedoe 45: 19-34

Grobler, C.H., G.J. BredenKamp, L.R. Brown. 2006. Primary grassland communities of urban open spaces in Gauteng, South Africa. South African Journal of Botany 72: 367-377.

Hoekstra J.M., T.M. Boucher, T.H. RicketTs \& C. RoBerts. 2005. Confronting a biome crisis: global disparities of habitat loss and protection. Ecology Letters 8: 23-29.

Land Type Survey Staff. 1984. Land types of the maps 2626 Wes-Rand, 2726 Kroonstad. Mem- oirs on the Agricultural Natural Resources of South Africa 4: 1-342.

Land Type Survey Staff. 1985. Land types of the maps 2628 East Rand. 2630 Mbabane. Memoirs on the Agricultural Natural Resources of South Africa 4: 1-261.

Land Type Survey Staff. 1987. Land types of the maps 2526 Rustenburg, 2528 Pretoria. Memoirs on the Agricultural Natural Resources of South Africa 8: 1-391.

Louw, W.J. 1970. Klipveld studies 1: Checklist of vegetation. Journal of South African Botany 36: 199-206

Minter, L.R., M. Burger, J.A. Harrison, H.H. BrAACK, P.J. Bishop \& D. KoEPFER (eds.). 2004. Atlas and Red Data Book of the Frogs of South Africa, Lesotho and Swaziland. Washington, DC: Smithsonian Institution.

MoLL, E.J. 1965. An account of the plant ecology of the upper Umgeni Catchment. MSc thesis, University of Natal, Pietermaritzburg

Mucina, L., Rutherford, M.C. \& L.W. Powrie (eds.). 2005. Vegetation map of South Africa, Lesotho \& Swaziland, 1:1000000 scale sheet maps. Pretoria: South African National Biodiversity Institute.

Smits, N.A.C., G.J. Bredenkamp, L. Mucina \& J.E. GRANGER. 1999. The vegetation of old fields in Transkei. South African Journal of Botany 65: 414-420

Weather Bureau. 2000. Prints of the climate statistics of the Johannesburg Leeukop, Pretoria Forum WB, Johannesburg Joubert Park and Krugersdorp Kroningspark weather stations. Pretoria: Department of Environment Affairs and Tourism. 